\title{
The Effect of Work Culture and Principal Leadership on Teachers' Work Discipline
}

\author{
Novi Nursilawati ${ }^{1 *}$, Happy Fitria ${ }^{2}$, Rohana $^{2}$ \\ ${ }^{1}$ SMPN 3 Babat Supat \\ ${ }^{2}$ Universitas PGRI Palembang \\ *Corresponding author. Email: ursilawatinovi@gmail.com
}

\begin{abstract}
This study aims to determine the effect of work culture and principal leadership on teacher work discipline. This type of research is descriptive quantitative. This research was conducted at SMPN in Babat Supat District, Musi Banyuasin Regency. The population in this study were 134 teachers, while a sample of 100 respondents was taken using the 5\% Slovin method. Data collection techniques in the form of questionnaires and documentation. The data analysis used the t-test, the F test, and the coefficient of determination (R Square) with calculations using the SPSS version 26 program. The results of the t-test and $\mathrm{f}$ test showed that the influence of work culture in the good category amounted to $48.95 \%$, the influence of the principal's leadership. in the good category amounted to $53.15 \%$ and the work discipline of the teacher was also in the good category, amounting to $46.16 \%$, while the results of the R Square analysis showed that the influence of work culture and principal leadership on teacher work discipline together was $36 \%$.
\end{abstract}

Keywords: Teacher Work Culture, Principal Leadership, Teacher Work Discipline.

\section{INTRODUCTION}

Work discipline is the awareness and willingness of employees to obey all organizational regulations and applicable social norms [1]. Work discipline is the ability of a person to work regularly, persistently and work in accordance with applicable rules without violating predetermined rules. Discipline is one of the factors that plays an important role in improving teachers' work performance [2],[3]. The discipline of teaching staff in carrying out their responsibilities will not be separated from various factors, including leadership and work culture [2]. Based on these two opinions, it means that an organization or institution will advance and achieve the desired goals if the level of discipline is high from all the elements in it.

Work culture is a philosophy as values that become traits, habits, and driving forces shared by each individual in the work environment of an organization [1]. Furthermore, the success of an employment is rooted in its values and habitual behavior. These values originate from customs, religions, norms and rules that become his beliefs into habits in work or organizational behavior. The values that have become habits are called culture. Because culture is associated with the quality or quality of work, it is called a work culture. Work culture, is a group of behavior patterns that are inherent as a whole in each individual in an organization. Building a culture also means increasing and maintaining positive sides, as well as trying to get used (habituating process) certain behavior patterns in order to create a new better form.

The importance of the principal's role as a leader has been proven by many education experts [4], [5], [6]. Human resource management is one of the most important competencies that should be had in a leader [7], [8]. The principal's leadership is very influential on improving teacher performance, so that it can encourage the achievement of organizational goals [9]. Effective leadership of the principal must be able to create a work climate that is conducive to achieving the goals of educational institutions. The indicators of the effective leadership abilities of school principals consist of 7 (seven) indicators, including being educators, managers, administrators, supervisors, leaders, innovators and motivators. To improve work discipline, leaders are required to be able to provide guidance, mobilize all potential employees in their environment with different leadership styles [10]. Leadership style is a method used by a leader in influencing the behavior of others. These kinds of styles have advantages and disadvantages. The style of a leader according to his personal abilities. He took advantage of his leadership style and was needed in leading his subordinates. Leadership style is a behavior norm that is used by someone when that person tries to influence the behavior of others.

Leadership includes the use of influence, that all relationships can involve leaders [3]. Leadership includes the importance of the communication process. 
The clarity and accuracy of communication affects the behavior and performance of followers. Leadership focuses on goals that are achieved [11]. Effective leaders must relate to a variety of individual, group, and organizational goals [12]. Thus, to achieve the positive goals of an educational institution, the work culture and leadership of the principal must be of good and high value.

This study focuses on the importance of teacher work discipline, because teachers are the front guard of a learning process in schools. In addition, the leadership of the principal is important in improving the discipline of a teacher. Babat Supat Subdistrict is one of the sub-districts in Musi Banyuasin Regency, there are eight Public Junior High Schools in Babat Supat District with teacher conditions, although they have limitations due to the distance from their residence to school, geographical conditions, infrastructure and educational facilities, however the teachers still have high work discipline to carry out the teaching and learning process in schools. This can be seen from the work culture of the teachers which has become a norm and habit in schools as well as the effectiveness of the principal's leadership in guiding, directing, delegating tasks, and supervising teachers.

However, there are still a small number of teachers who have a low level of discipline and work culture in carrying out their duties and obligations and there are still principals who are still deemed ineffective in carrying out leadership in schools but overall teacher work discipline at SMPN in Babat Supat District, Musi Banyuasin Regency is still in a good category. Departing from the above background, the authors are interested in conducting this study to find out: 1) whether or not there is an effect of work culture on teacher work discipline at State Junior High Schools in Babat Supat District, Musi Banyuasin Regency, 2) whether or not there is an effect of the principal's leadership on the work discipline of teachers of State Junior High Schools in Babat Supat District, Musi Banyuasin Regency, 3) whether or not there is an effect of the work culture and school principal leadership on the work discipline of state junior high school teachers in Babat Supat District, Musi Banyuasin Regency.

\section{METHODS}

This is an explanatory research using a quantitative approach. Data collection techniques used are a questionnaire / questionnaire and documentation [13], [14], [15]. The population of this study is 134 teachers at SMPN Babat Supat subdistrict with a random sample of 100 teachers.

\section{RESULTS AND DISCUSSION}

\section{Normality test}

The normality test in this study used the KolmogorovSmirnov test using SPSS 26.00. The results of the normality test can be seen in Table 1 .
Table 1. The Results of Normality Test

One-Sample Kolmogorov-Smirnov Test

\begin{tabular}{|ll|r|}
\hline$N$ & 100 \\
Norma & Mean & .000000 \\
1 & Std. Deviation & \\
Param & & 4.60041591 \\
ters $^{\mathrm{a}}$ & & .065 \\
Most & Absolute & .044 \\
Extre & Positive & \\
me & Negative & -.065 \\
Differ & & .648 \\
ences & & .795 \\
Kolmogorov-Smirnov Z & \\
Asymp. Sig. (2-tailed) & \\
\hline
\end{tabular}

From Table 1 above, it can be stated that from the One-Sample Kolmogorov-Smirnov Test, the sig (2-tailed) value is obtained of 0.795 . The sig value of 0.795 exceeds 0.05 . Thus, it can be stated that all data are normally distributed. Normality test is useful for testing whether the regression model, the dependent variable and the independent variable have a normal distribution or not. The normality test in this study uses the distribution on the P-P plot graph. The results of the normality test using the P-P Plot chart using the SPSS version 26 application are presented in Figure 1.

Normal P-P Plot of Regression Standardized Residual

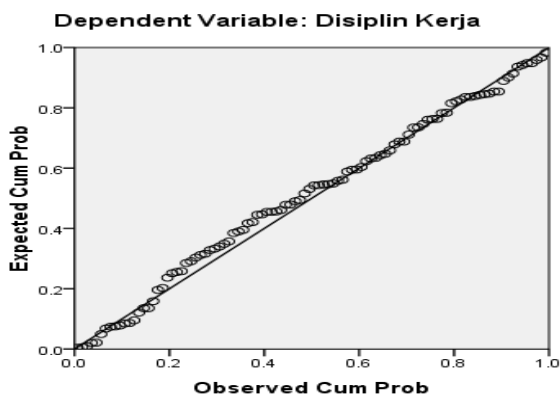

Figure 1. The results of P-P plot Analysis

Based on Figure 1 above, it can be seen that the data spreads around the diagonal line and follows the direction of the diagonal line on the histogram graph, this shows that the distribution pattern is normal. Therefore, it is concluded that based on the P-P plot graph, the regression model fulfills the normality assumption.

Multiple Linear Regression Analysis Test The results of Multiple Linear Regression Analysis are presented in Table 2.

Table 2. Results of Multiple Linear Regression Analysis

\begin{tabular}{|c|c|c|c|}
\hline \multicolumn{4}{|c|}{ Multiple Linear Regression Analysis } \\
\hline Variable & $\begin{array}{l}\text { Coefficient } \\
\text { Regresses }\end{array}$ & $\mathrm{T}_{\text {count }}$ & Sig. \\
\hline Constant & 26,936 & 2,483 & 0,015 \\
\hline Work Culture $\left(\mathrm{X}_{1}\right)$ & 0,211 & 2,675 & 0,009 \\
\hline Leadership $\left(\mathrm{X}_{2}\right)$ & 0,523 & 5,754 & 0,000 \\
\hline \multicolumn{4}{|l|}{$\mathrm{F}_{\text {count }}=27,264$} \\
\hline $\mathrm{R}_{\text {square }}=0,360$ & & & \\
\hline
\end{tabular}


First Hypothesis Testing ( $H_{1}$ )

Table 3. Results of $t$-test analysis for variable $\mathrm{X} 1$ against $\mathrm{Y}$

Coefficients $^{\mathrm{a}}$

\begin{tabular}{cccccc}
\hline \multirow{2}{*}{ Model } & \multicolumn{2}{c}{$\begin{array}{c}\text { Unstandardized } \\
\text { Coefficients }\end{array}$} & $\begin{array}{c}\text { Standardized } \\
\text { Coefficients }\end{array}$ & & \\
\cline { 2 - 4 } & $\mathrm{B}$ & $\begin{array}{c}\text { Std. } \\
\text { Error }\end{array}$ & Beta & & Sig. \\
\cline { 2 - 5 } & & & & \\
\hline $\begin{array}{c}\text { (Constant) } \\
1\end{array}$ & 26.936 & 10.846 & & 2.483 & .015 \\
\hline $\begin{array}{c}\text { Work } \\
\text { Culture }\end{array}$ & .211 & .079 & .228 & 2.675 & .009 \\
\hline
\end{tabular}

As presented in Table 3, the $t_{\text {count value is 2,675> }}$ from the t-table (1.661), so $\mathrm{Ho}_{1}$ is rejected. It means, there is a significant effect of work culture on the work discipline of teachers of SMP Negeri in Babat Supat District.

Second Hypothesis Testing $\left(\mathrm{H}_{2}\right)$

Table 4. Results of t-test analysis for variable $X_{2}$ against $Y$

\begin{tabular}{|c|c|c|c|c|c|}
\hline \multirow[b]{3}{*}{ Model } & \multicolumn{3}{|c|}{ Coefficients $^{\mathrm{a}}$} & \multirow[b]{3}{*}{$\mathrm{t}$} & \multirow[b]{3}{*}{ Sig. } \\
\hline & \multicolumn{2}{|c|}{$\begin{array}{c}\text { Unstandardized } \\
\text { Coefficients }\end{array}$} & $\begin{array}{l}\text { Standardized } \\
\text { Coefficients }\end{array}$ & & \\
\hline & B & $\begin{array}{c}\text { Std. } \\
\text { Error }\end{array}$ & Beta & & \\
\hline 1 (Constant) & 26.936 & 10.846 & & 2.483 & .015 \\
\hline Leadership & .523 & .091 & .490 & 5.754 & .000 \\
\hline
\end{tabular}

As presented in Table 4, the $\mathrm{t}_{\text {count }}$ value is $\mathbf{5 . 7 5 4}$ $\geq$ the $\mathrm{t}$ table is 1.661 . This means, $\mathrm{Ho}_{2}$ is rejected. Therefore, it is concluded that there is a significant effect of the principal's leadership on the teachers' work discipline.

Third Hypothesis Testing $\left(\mathrm{H}_{3}\right)$

Table 5. The Results of the F Test Analysis

\begin{tabular}{|c|c|c|c|}
\hline \multicolumn{4}{|c|}{ Coefficients $^{\mathrm{a}}$} \\
\hline & & \multicolumn{2}{|c|}{ Unstandardized Coefficients } \\
\hline \multicolumn{2}{|c|}{ Model } & B & Std. Error \\
\hline \multirow[t]{3}{*}{1} & (Constant) & 26.936 & 10.846 \\
\hline & Work Culture & .211 & .079 \\
\hline & Leadership & .523 & .091 \\
\hline
\end{tabular}

Based on the results of multiple regression tests, the regression equation constant value (a) is 26.936 and the coefficient value of the independent variable (b1) is 0.211 and the value (b2) is 0.523 , then the regression equation is obtained as follows.

$\mathrm{Y}=\mathrm{a}+\mathrm{b}_{1} \mathrm{X}_{1}+\mathrm{b}_{2} \mathrm{X}_{2}$

$Y=26,936+0,211 X_{1}+0,523 X_{2}$

This means that teacher work discipline has increased positively through the influence of work culture and principal leadership. To find out the truth of hypothesis testing, a simultaneous test was carried out using the $\mathrm{F}$ test to determine the influence of the influence of work culture and principal leadership on variables of teacher work discipline. The results of multiple regression analysis can be seen in Table 6 .

Table 6. The Results of Multiple Regression Analysis

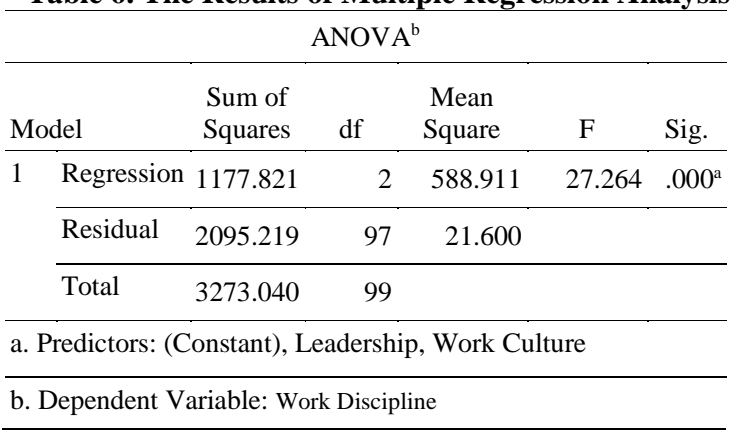

As presented in Table 6 , it is obtained $F_{\text {count }}$ of 27.264 with a significance level of 0.000 <probability value $\alpha 0.05$, while $F_{\text {table }}$ corresponds to a significance level of 0.05 of 2.465 . Because $F_{\text {count }}$ is higher than $F_{\text {table }}(27.264>2.465), \mathrm{Ho}_{3}$ is rejected. It means, there is a significant effect coincidentally, the effect of work culture and principal leadership on the work discipline of the teachers.

Analysis of the Determination Coefficient Tes $\left(R^{2}\right)$ To find out how much influence the independent variable has on the dependent variable simultaneously, it can be seen in Table 7 .

Table 7. The Results of the Determination Coefficient Test

\begin{tabular}{|c|c|c|c|c|c|}
\hline \multicolumn{6}{|c|}{ Model Summary ${ }^{\mathrm{b}}$} \\
\hline Model & $\mathrm{R}$ & $\begin{array}{c}\mathrm{R} \\
\text { Square }\end{array}$ & $\begin{array}{c}\text { Adjusted R } \\
\text { Square }\end{array}$ & $\begin{array}{l}\text { Std. Error of } \\
\text { the Estimate }\end{array}$ & $\begin{array}{l}\text { Durbin- } \\
\text { Watson }\end{array}$ \\
\hline 1 & $.600^{\mathrm{a}}$ & .360 & .347 & 4.648 & 2.612 \\
\hline \multicolumn{6}{|c|}{ a. Predictors: (Constant), Leadership, Work Culture } \\
\hline \multicolumn{6}{|c|}{ b. Dependent Variable: Work Discipline } \\
\hline
\end{tabular}

As presented in Table 7, the $\mathrm{R}$ square value is 0.360 , thus the termination coefficient is $36.0 \%$. It can be concluded that the influence of work culture and principal leadership on the work discipline collectively is $36 \%$, and the remaining $64 \%$ (100 - 36) are influenced by other factors not examined in this study.

The results of statistical descriptive analysis show that the effect of work culture are as follows: as follows: Very Good $=0(0 \%)$, Good $=70(48.95 \%)$, good Enough= $40(27.97 \%)$, Less $=17(11.89 \%)$, and Very Poor $=16(11.19 \%)$. The results of the analysis indicate that the effect of work culture is in the Good category. Then the results of the analysis of the statistical descriptions of the principal's leadership are as follows: Very Good $=0(0 \%), \operatorname{Good}=76(53.15 \%)$, Good Enough $=31(21.68 \%)$, Less $=24(16.78 \%)$, and 
Very Poor $=12(8.39 \%)$. The results of the analysis indicate that the leadership of the headmaster of the SMP Negeri in Babat Supat District is in a Good category. The results of the teacher work discipline are: Very Good $0(0 \%)$, Good $=66(46.16 \%)$, Good Enough $=44(30.77 \%)$, Less $=22(15.38 \%)$, Very Poor $=11(7.69 \%)$. The results of the analysis indicate that the teacher's work discipline is in Good category. From the results of the descriptive statistical test it can be seen that all research variables, namely work culture, principal leadership and teacher work discipline are in good categories.

\section{a) The Effect of Work Culture on Teacher Work Discipline}

Based on the simple regression test above, since the $t_{\text {count }}$ value is higher than $t_{\text {table }}, H_{1}$ is rejected. Thus, there is a significant effect of work culture on the work discipline. The results indicate that the principal through his role as a leader plays an important role in improving work culture for teacher work discipline.

\section{b) The Effect of Principal Leadership on Teacher Work Discipline}

Based on the significance test of the principal's leadership variable on the work discipline of the teachers, the $t_{\text {count }}$ value is higher the $t_{\text {table, }}$, so there is a significant effect of the principal's leadership on the work discipline. This result indicates that the higher the principal's leadership in managing the learning process, the higher the teacher's work discipline.

c) The Influence of Work Culture and Principal Leadership on Teacher Work Discipline

The third hypothesis was tested with multiple regression analysis. Because the value of $F_{\text {count }}$ (27.264) with a significance level of 0.000 is less than the probability value $(\alpha 0.05), \mathrm{Ho} 3$ is rejected. Therefore, there is a significant effect of work culture and school principal leadership on the work discipline of teachers of SMP Negeri in Babat Supat District.

\section{d) Determination Coefficient Test Results $\left(R^{2}\right)$}

Based on the $\mathrm{R}$ square value of 0.360 , it means that the coefficient of determination is $36 \%$, so it can be concluded that the effect of work culture and school leadership on the work discipline of teachers of SMP Negeri in Babat Supat District is 36\% and the rest is $64 \%$ (100-36) is influenced by other factors which are not examined in this study.

\section{CONCLUSION}

Based on the results of the study, the following conclusions can be drawn: (1) there is an effect of the work culture of the teachers on the work discipline of teachers of State Junior High Schools in Babat Supat District, Musi Banyuasin Regency; (2) there is an effect of the principal's leadership on the work discipline of teachers of State Junior High Schools in
Babat Supat District, Musi Banyuasin Regency. (3) there is an effect of the work culture of the teacher and the leadership of the principal together on the work discipline of teachers of the State Junior High School in Babat Supat District, Musi Banyuasin Regency.

\section{REFERENCES}

[1] Sinambela, L. P., \& Sarton, S. (2019). Manajemen Kinerja Pengelolaan, Pengukuran, dan Implikasi Kinerja. Depok: Rajagrafindo Persada.

[2] Hasibuan, M. S. P. (1994). Peningkatan Disiplin Kerja. Jakarta: BumiAksara.

[3] Mills, M., \& Goos, M. (2007). Productive pedagogies: Working with Disciplines and Teache and Student Voices. Paper Presented at the annual conference of the Australian Association for Research in Education, Fremantle.

[4] Rahmawan. (2009). Analisis Pengaruh Kepemimpinan, Intensif dan Motivasi Kerja terhadap Disiplin Kerja pada Pegawai Dinas Lingkungan Hidup Kabupaten Magelang.

[5] Royani, I. (2020). "Pengaruh Kepemimpinan Kepala PAUD dan Kompetensi Guru Terhadap Kinerja Guru" Journal of Inovation in Teaching and Instructional Media 1 (1),36-45.

[6] Syahril, B. (2013). "Pengaruh Gaya Kepemimpinan Kepala Sekolah, Sikap Guru dan Disiplin Kerja Guru Terhadap Kinerja Guru SMA Negeri Di Kota Manna Bengkulu Selatan" (Thesis, Universitas Bengkulu)

[7] Hadari, N. (2003). Manajemen Sumber Daya Manusia. Cetakan kelima, Gajah Mada University Press, Yogyakarta.

[8] Handoko, H. (2000). Manajemen Personalia dan Sumber Daya Manusia, Yogyakarta: BPFE

[9] Siagian, S. P. (2008). Manajemen Sumber Daya Manusia. Jakarta: Bumi Aksara.

[10] Siswanto, B. (2012). Manajemen Tenaga Kerja Indonesia Pendekatan Administrasi dan Operasional. Jakarta: Bumi AksaraSalusu, J.2000. Pengambilan Keputusan Strategik, Untuk Organisasi Publik dan Organisasi Non Profit, Jakarta: PT. Gramedia Pustaka Utama.

[11] Soewarno, H. (2001). Pengantar Studi Ilmu Administrasi dan Manajemen. Cetakan ke-14, CV. Haji Masagung, Jakarta.

[12] Stephen P. R. (2003). Perilaku Organisasi. Alih bahasa Tim Indeks, Edisi Indonesia, PT. Indeks Gramedia Group, Jakarta.

[13] Arikunto, S. (2006). Prosedur Penelitian Suatu Pendekatan Tehnik. Jakarta: Rieneka Cipta

[14] Setiaji, B. (2004). Panduan Riset Dengan Pendekatan Kuantitatif. Program Surakarta: Pascasarjana UMS.

[15] Sugiyono. (2013). Metode Penelitian Kuantitatif, Kualitatif, Kombinasi (Mixed Methods). Bandung: Alfabeta. 